\title{
Studies on Effect of Intercrops on Initial Growth Stages of Bamboo under Spices - Bamboo Based Agroforestry System in Tropical Regions of Jharkhand
}

\author{
P.V. Dhanyashri ${ }^{1 *}$, M.S. Malik ${ }^{1}$, M.C. Shashikumar ${ }^{3}$, Yogesh Kumar Agarwal' \\ Saraswati Sahu ${ }^{1}$ and M. Jadegowda ${ }^{3}$
}

\author{
${ }^{1}$ Department of Silviculture and Agroforestry, Faculty of Forestry, Birsa Agricultural \\ University, Kanke, Ranchi, Jharkhand-834006, India \\ ${ }^{2}$ Department of Silviculture and Agroforestry, College of Forestry, SHUATS, \\ Prayagraj-211007, India \\ ${ }^{3}$ Department of Natural Resources and Management, College of Forestry Ponnampet, India
}

*Corresponding author

\begin{tabular}{|l|}
\hline Ke y w o r d s \\
Agroforestry \\
system, Bamboo, \\
Coriander, Fennel, \\
Fenugreek, Height \\
growth, Collar \\
diameter and \\
number of culms
\end{tabular}

Intercropping with short-term crops provides a significant additional income during the long immature period of bamboo plant growth. Much previous evidence has demonstrated that the growth of young bamboo plants. Bamboo based agroforestry systems are socially and economically viable and more sustainable than many other croprotations prevalent in eastern India. However, few, if any studies have however been conducted to date to assess the effects of intercropping on subsequent growth and yield of bamboo plants. Fennel, Coriander and Fenugreek were grown as intercrops under agroforestry system at farm campus of Ranchi Veterinary College, B.A.U Agroforestry field during 'Rabi' season 2018-19. The four treatment combinations were $\mathrm{T}_{1}$ Bamboo (B. nutans - Wall. ex Munro) + Sounf (Foeniculum vulgare Mill.), $\mathrm{T}_{2} \mathrm{Bamboo}$ (B. nutans- Wall. ex Munro) + Dhania (Coriandrum sativum L.), $\mathrm{T}_{3}$ Bamboo (B. nutans- Wall. ex Munro) + Methi (Trigonellafoenum-graecum Linn.) and $\mathrm{T}_{4} \mathrm{Bamboo}$ (B. nutans- Wall. ex Munro [Sole]). The growth performance of the Bambusa nutans was varies from treatment to treatment under agroforestry system. The maximum increment in plant height $(0.86 \mathrm{~m})$ was found in $\mathrm{T}_{3}$ Bamboo and least was found in $\mathrm{T}_{4}$ Sole Bamboo $(0.58 \mathrm{~m})$. The increment in collar diameter was also more in case of $\mathrm{T}_{1}$ Bamboo + Fennel $(2.62 \mathrm{~m})$ and minimum in $\mathrm{T}_{2}$ Bamboo + Coriander $(1.86 \mathrm{~m})$. The maximum increment in number of culms was found in $\mathrm{T}_{2}$ Bamboo + Coriander (2.13) treatment and minimum observed in $\mathrm{T}_{1}$ Bamboo + Fennel (1.97). 


\section{Introduction}

Agroforestry, a traditional practice of combining trees with agricultural crops or pasture, can contribute substantially in this direction through its multiple benefits and ecosystem services. If properly designed, agroforestry may help in alleviating poverty, providing food security and livelihood, maintaining ecosystem health, managing pest and weeds, conserving biodiversity, and mitigating greenhouse effects by carbon sequestration. The common hypothesis which restricts to combine the trees and crops together is that the tree production is realized only at the expense of crop growth (Cannell, 1996). If the trees deprive the crop of shared resources in limited supply, crop production in agroforestry will be impaired (Anderson and Sinclair, 1993). It is therefore critical for the success of agroforestry that competition. Gill et al. (2008) reported that inter cropping of lemon grass, Tagetes minuta, turmeric, celery, coriander, fennel, dill reed, fenugreek, mentha species and mustard with poplar trees increased the dbh and height of poplar tree. Malik et al. (2011) have conducted research on bamboo based agroforestry system in Jharkhand atDarisai, East Singhbhum and found that agroforestry activity particularly intercropping with bamboo is helpful in increase of production of bamboo as well as agricultural crops. Hence, a major challenge for management of agroforestry is to control competition and encourage 'complementarity' between trees and crops. Complementarity occurs when components of mixed vegetation utilize spatially or temporally distinct sources and consequently avoid competition (Anderson and Sinclair, 1993). A study on intercropping of the horticultural trees with annual crops has been carried out (Reddy et al., 1992; Reddy and Willey, 1981). However, no information is, available on suitability of intercrop which can be grown in association with citrus, mopane and shisham in arid region. The present experiment was therefore, conducted to study the suitability of intercrops in agri-horti-sivi systems of citrus, mopane and shisham under sprinkler irrigation. There is a need to establish a novel method to combat the diseases. In this scenario, coriander being an ancient herb and spice is imperative owing to its accessibility, low cost, and allied therapeutic claims (Sharma and Sharma, 2012). India, the land of spices is the world's largest producer, consumer and exporter of spices. A spice is a dried seed, fruit, root, bark or vegetative substance used in flavouring, seasoning and imparting aroma in variety of food items and beverages. It is known as "Home of Spices" in India. It is the time that greater attention devoted to economically and ecologically sustainable agricultural production system, to design more efficient and ecologically sustainable agoforestry systems to overcome physiological, biological, ecological and economic constraints and should aim to achieve the highest possible output per unit of land, water, time and labour (Venkatrao, 2005).

\section{Materials and Methods}

The study was conducted at Ranchi Veterinary College, Kanke, Ranchi District of Jharkhand, India. The study site is located in plain region of Chotanagpur Plateau of Jharkhand, which is situated at a distance of about is $3.5 \mathrm{~km}$ east from Faculty of Forestry, Birsa Agricultural University, Ranchi. The district is situated between $23^{\circ} 30^{\prime}$.around 651 $\mathrm{m}$ from mean sea level. The district covers an area of $5097 \mathrm{~km}^{2}$ to find out the effect of Fennel, Coriander and Fenugreek crops on Bamboo in Rabi 2018-2019. Ranchi has a humid subtropical climate. However, due to its position and the forests around the city, it is known for its pleasant climate. Ranchi used to be a preferable hill station in the past. Temperature ranges from maximum 42 to $20^{\circ} \mathrm{C}$ during summer and from 25 to $0^{\circ} \mathrm{C}$ during winter. December and January are the 
coolest months with temperature getting to freezing point in some places of the city. The annual rainfall is about $1430 \mathrm{~mm}(56.34$ inches). From June to September the rainfall is about $1,100 \mathrm{~mm}$. The total area covered by the Ranchi municipal area is 175.12 square kilometers and the average elevation of the city is $651 \mathrm{~m}$ above sea level. The 7 treatments combinations consisting of methods of sowing viz., raised bed, and time of sowing under open and shaded conditions in all possible combinations were tested in RBD (factorial) with three replications.

The Bamboo (Bambusa nutans) plant was planted in the year 2018 at the spacing of $5 \mathrm{~m}$ x $6 \mathrm{~m}$. Simultaneously experiment was laid out for the purpose of improvement of bamboo stock with intercropping of selected spice crops such as Fenugreek, Coriander and fennel crops.

\section{Details of the measurements}

\section{Culm height}

The length between collar and tip of shoot was considered as culm height. The culm height of bamboo tree was measured by using meter tape in $\mathrm{cm}$ at the initial and at the end of the experiment and mean value was calculated.

\section{Culm diameter}

Culm diameter of bamboo was measured at collar diameter, by using of digital caliper in the interest of accuracy.

\section{Average number of culms per clump}

The total number of culms were counted at the end of the experiment and average number of culms per treatment were calculated.

\section{Results and Discussion}

The data's (Table: 1, 2 and 3) showed the different growth characteristics of Bamboo (Bambusa nutans) under Bamboo-Based agoforestry system.

The maximum increment in height of Bamboo (Bambusa nutans) was found in $\mathrm{T}_{3}$ Bamboo + Fenugreek $(0.86 \mathrm{~m})$ which was found at par with the treatment $\mathrm{T}_{2}$ Bamboo + Coriander $(0.79 \mathrm{~m})$ followed by $\mathrm{T}_{1}$ Bamboo + Fennel $(0.66 \mathrm{~m})$ and minimum in $\mathrm{T}_{4}$ Sole Bamboo (0.58 m).

The highest increment in collar diameter of Bamboo (Bambusa nutans) was found in $\mathrm{T}_{1}$ (Bamboo + Fennel) $(2.62 \mathrm{~m})$ which was at par with $\mathrm{T}_{4}$ Sole Bamboo (2.29 m) followed by $\mathrm{T}_{3}$ Bamboo + Fenugreek $(1.96 \mathrm{~m})$ while minimum in $\mathrm{T}_{2}$ Bamboo + Coriander (1.86 $\mathrm{m})$.

It was also observed that the maximum increment in number of culms per clump of Bamboo (Bambusa nutans) was found in $\mathrm{T}_{2}$ Bamboo + Coriander (2.13) followed by $\mathrm{T}_{4}$ Sole Bamboo (2.07) and $\mathrm{T}_{3}$ Bamboo + Fenugreek (2.02) and minimum in $\mathrm{T}_{1}$ Bamboo + Fennel (1.97). Among treatments all were at par with each other and no significance differences occurred. The improvements in growth characteristics were occurred more under combination treatments might because of the influence of the intercrops on bamboo at the intial stages of bamboo growth, intercrops helps in preserving the soil moisture and enhances the overall nutrients status of the soil. Similar findings were reported by Gill and Roy (1992) on the growth of Leucaena leucocephala and mango based intercropped agroforestry system at Jhansi. 
Table.1 Average Height Growth of Bamboo (Bambusa nutans) under Bamboo Based Agroforestry System during the period of 6 months

\begin{tabular}{|c|c|c|c|c|}
\hline \multirow{2}{*}{ Treatments } & \multicolumn{3}{|c|}{ Height (m) } \\
\cline { 2 - 5 } & Initial & Final & Increment & Percent Increment \\
\hline $\mathbf{T}_{\mathbf{1}}$ & 0.53 & 1.18 & 0.66 & 126.18 \\
\hline $\mathbf{T}_{\mathbf{2}}$ & 0.58 & 1.37 & 0.79 & 136.29 \\
\hline $\mathbf{T}_{\mathbf{3}}$ & 0.61 & 1.48 & 0.86 & 137.47 \\
\hline $\mathbf{T}_{\mathbf{4}}$ & 0.45 & 1.05 & 0.58 & 123.41 \\
\hline & & Mean & 0.72 & \\
\hline & & SE (m) \pm & 0.03 & \\
\hline & & C.D $(\mathbf{5 \%})$ & 0.12 & \\
\hline & & C.V. $(\mathbf{\%})$ & 7.92 & \\
\hline
\end{tabular}

Table.2 Average collar diameter growth of Bamboo (Bambusa nutans) under Bamboo Based Agroforestry System during the period of 6 months

\begin{tabular}{|c|c|c|c|c|}
\hline \multirow{2}{*}{ Treatments } & \multicolumn{4}{|c|}{ Collar Diameter (cm) } \\
\cline { 2 - 5 } & Initial & Final & Increment & Percent Increment \\
\hline $\mathbf{T}_{\mathbf{1}}$ & 1.49 & 4.09 & 2.62 & 179.61 \\
\hline $\mathbf{T}_{\mathbf{2}}$ & 2.32 & 4.21 & 1.86 & 79.62 \\
\hline $\mathbf{T}_{\mathbf{3}}$ & 2.54 & 4.51 & 1.96 & 74.03 \\
\hline $\mathbf{T}_{\mathbf{4}}$ & 1.25 & 3.57 & 2.29 & 191.05 \\
\hline & & Mean & 2.18 & \\
\hline & & SE (m) \pm & 0.12 & \\
\hline & & C.D $(\mathbf{5 \%})$ & 0.44 & \\
\hline & & C.V. $(\mathbf{\%})$ & 9.87 & \\
\hline
\end{tabular}

Table.3 Average increase in the number of culms / clump of Bamboo (Bambusa nutans) under Bamboo Based Agroforestry System during the period of 6 months

\begin{tabular}{|c|c|c|c|c|}
\hline \multirow{2}{*}{ Treatments } & \multicolumn{4}{|c|}{ Number of culms/clump } \\
\cline { 2 - 5 } & Initial & Final & Increment & Percent Increment \\
\hline $\mathbf{T}_{\mathbf{1}}$ & 2.45 & 4.45 & 1.97 & 80.45 \\
\hline $\mathbf{T}_{\mathbf{2}}$ & 2.56 & 4.68 & 2.13 & 83.23 \\
\hline $\mathbf{T}_{\mathbf{3}}$ & 2.74 & 4.75 & 2.02 & 73.54 \\
\hline $\mathbf{T}_{\mathbf{4}}$ & 2.25 & 4.32 & 2.07 & 91.92 \\
\hline & & Mean & 2.05 & \\
\hline & & SE (m) \pm & 0.08 & \\
\hline & & C.D $\mathbf{( 5 \% )}$ & 0.26 & \\
\hline & & C.V.(\%) & 6.38 & \\
\hline
\end{tabular}

A similar observations was also given by Gill et al. (2008) and reported that inter cropping of lemon grass, Tagetes minuta, turmeric, celery, coriander, fennel, dill reed, fenugreek, mentha species and mustard with poplar trees increased the dbh and height of poplar tree. 
It may be concluded that the increase in increments of different growth parameters were recorded under the different treatment combinations as compared to sole cropping. The maximum increment in plant height, was found in $\mathrm{T}_{3}$ treatment, the increment in collar diameter was also more in case of $T_{1}$ treatment. The maximum increment in number of culms was found in $\mathrm{T}_{2}$ (2.13) treatment. Intercrops will always be a source of additional income to the bamboo growers rather keeping the interspace fallow. Bamboo is one of the commercial plant for the farmers of the state. Experiments should also be conducted with different agricultural crops with different varieties of bamboo. Bamboo is one of the commercial plant for the farmers of the state. Experiments should also be conducted with different agricultural crops with different varieties of bamboo. Further studies should be conducted for better improvements.

\section{References}

Anderson, L.S. and Sinclair, F.L. 1993. Ecological interactions in agroforestry systems. Agroforestry Abstracts 6: 5791.

Cannell, M.G.R., Van Noordwijk, M. and Ong, C.K. 1996. The central hypothesis: Trees must acquire resources that the crop would not otherwise acquire. Agroforestry Systems 33: 27-31.

Gill, A. S. and Roy, R. D. (1992). Growth of Leucaena leucocephala in mango based intercopped agroforestry system. Lecaena Reports, 13 : 22-25.

Gill, B. S., Singh, A., Singh, D. and Gandhi, N. (2008).Studies on intercropping of medicinal, aromatic and spice crops in poplar plantation. Indian Journal of Agronomy, 53 (4) : 295-298.

Gill, B. S., Singh, A., Singh, D. and Gandhi, N. (2008).Studies on intercropping of medicinal, aromatic and spice crops in poplar plantation. Indian Journal of Agronomy, 53 (4) : 295-298.

Malik, M. S. Kaushal, P. and Sah, R. B. (2011). Development of bamboo based agroforestry farming system in Jharkhand. In : project report of Development of bamboo based agroforestry farming system in Jharkhand, 2011, Birsa Agricultural University; 1-37 pp.

Reddy, K.C.P. Visser and Buckner, P. 1992. Pearl millet and cowpea yields in sole and intercrop system and their effects on soil and crop productivity. Field Crops Research 4: 113-124.

Reddy, M.S. and Willey, R.W. 1981. Growth and resource use studies in an intercrop of pearl millet/groundnut. Field Crops Research 4: 13-24.

Sharma, M. M., Sharma, R. K. (2012) Coriander. In: Peter K.V., (ed) Handbook of herbs and spices, 2nd edn, vol 1. Wood head Publishing series in food science, technology, and nutrition, no. 227. Woodhead Publishing Limited, Cambridge, UK, 216-249 pp.

\section{How to cite this article:}

Dhanyashri, P.V., M.S. Malik, M.C. Shashikumar, Yogesh Kumar Agarwal, Saraswati Sahu and Jadegowda, M. 2020. Studies on Effect of Intercrops on Initial Growth Stages of Bamboo under Spices - Bamboo Based Agroforestry System in Tropical Regions of Jharkhand. Int.J.Curr.Microbiol.App.Sci. 9(07): 1112-1116. doi: https://doi.org/10.20546/ijcmas.2020.907.130 